\title{
KOMPETENSI GURU BAHASA ARAB DALAM MENGIMPLEMENTASIKAN KURIKULUM 2013
}

\author{
Titin Fatimah \\ Program Studi Pendidikan Bahasa Arab, FTIK, IAIN Palu \\ titindeden@gmail.com
}

\begin{abstract}
ABSTRAK
Kurikulum 2013 pada mata pelajaran Bahasa Arab pada prinsipnya sama dengan tuntutan prosedur pembelajaran mata pelajaran lainnya yang menuntut tanggung jawab dan kompetensi guru dalam mengimplementasikan secara kreatif dan inovatif. Idealitas pembelajaran Kurikulum 2013 tersebut secara faktual sampai saat ini belum terealisasi sebagaimana mestinya oleh karena terkait pada aspek kompetensi guru. Kompetensi pedagogik, sebagai salah satu aspek kompetensi yang mutlak melekat pada guru masih ditemukan di lapangan belum cukup memadai pada guru, termasuk guru Bahasa Arab di MTs. Negeri Kota Palu, terutama pada sub kompetensi kemampuan merancang dan mengembangkan rencana pembelajaran sesuai standar Kurikulum 2013 dan tuntutan penguatan literasi, Higher of Thingking Skills (HoTS) dan 4C. Kendala pengimplementasian dan penerapan kompetensi pedagogik guru dikelompokka ke dalam dua kategori kendala, yaitu: kendala internal dan kendala eksternal sehingga diperlukan upaya serius dan strategis dalam mengatasi kelemahan kompetensi guru dalam pembelajaran.
\end{abstract}

Kata Kunci : Kompetensi, Guru Bahasa Arab, Kurikulum 2013

\section{ABSTRACT}

The 2013 curriculum in Arabic subjects is same as the demands of learning procedures for other subjects that require teacher responsibility and competence in implementing creatively and innovatively. The ideality of learning in the 2013 Curriculum in fact has not been realized as it should be because it is related to aspects of teacher competence. Pedagogic competence, as one of the aspects of competence that is absolutely inherent in teachers, is still found in the field to be insufficient for teachers, including Arabic teachers at MTs. Negeri Palu, especially in the sub-competency ability to design and develop learning plans according to the 2013 Curriculum standards and the demands of strengthening literacy, Higher of Thingking Skills (HoTS) and 4C. The Problem to the implementation and application of teacher pedagogical competences are grouped into two categories, namely: internal constraints and external constraints so that serious and strategic efforts are needed to overcome the weaknesses of teacher competence in learning

Keywords: Competence, Arabic Teacher, The 2013 curriculum

\section{PENDAHULUAN}

Implementasi Kurikulum 2013 untuk mata pelajaran Bahasa Araba pada Madrasah di lingkungan Kementerian Agama telah diterapkan di beberapa tingkat satuan pendidikan menengah atau Madrasah Tsanawiyah (MTs) dan Madrasah Aliyah (MA), baik negeri maupun swasta sejak pada tahun pelajaran 2014 . Namun, efektif pengimplementasian Kurikulum 2013 secara efektif di semua tingkatan sekolah/madrasah di lingkungan Kementerian Agama, baru mulai efektif pada tahun 2016, termasuk di Kota Palu.

Pada tataran pembelajaran, implementasi Kurikulum 2013 mengarahkan proses pembelajaran menggunakan pendekatan scientifc yang mendorong peserta didik untuk terlibat secara aktif dan proaktif melakukan 
pengamatan (observing), bertanya (questioning), menalar (associating), mencoba (experimenting), dan membentuk jejaring (networking). Dengan demikian, proses pembelajaran secara utuh melahirkan kualitas pribadi yang mencerminkan keutuhan penguasaan sikap, pengetahuan, dan keterampilan yang dinilai secara holistik dan autentik (Arif \& Indra, 2013).

Melihat konsep ideal dan pergeseran paradigma pembelajaran Kurikulum 2013 tersebut, menuntut tanggung jawab dan kompetensi guru dalam mengimplementasikan secara kreatif dan inovatif. Kompetensi guru bukan saja berkaitan dengan penguasaan apa yang harus dibelajarkan (content) tetapi bagaimana membelajarkan peserta didik dengan setting pembelajaran yang produktif, inovatif, kreatif, dan afektif berbasis scientific sebagaimana yang dikehendaki di dalam pembelajaran Kurikulum 2013 (Mulyasa, 2014). Kompetensi adalah suatu hal yang menggambarkan kualifikasi atau kemampuan seseorang, baik yang kualitatif maupun yang kuantitatif. M. Ahsan mengemukakan bahwa kompetensi adalah kemampuan melaksanakan sesuatu yang diperoleh melalui pendidikan dan pelatihan yang bersifat kognitif, afektif, dan psikomotorik dengan sebaik-baiknya (2008). Dengan demikian, kompetensi merupakan perpaduan dari pengetahuan, keterampilan, nilai sikap yang telah menjadi bagian dari diri seseorang yang direfleksikan dalam kebiasaan berpikir dan bertindak.

Istilah kompetensi guru pada dasarnya diartikan sebagai kemampuan yang dimiliki seorang guru. Kompetensi guru di sini mengacu pada pengertian; (1) kompetensi dalam pengertian kemampuan karena adanya kecakapan dan keterampilan yang dimiliki oleh guru dalam mengelola tugas-tugas keguruan; dan (2) kompetensi dalam pengertian kewenangan atau hak mengelola tugas-tugas keguruan dan menetapkan keputusan hasil kerjanya secara berkualitas (Anang, 2013).

Salah satu aspek kompetensi yang mutlak dimiliki oleh setiap guru, adalah kompetensi pedagogik yang menjadi fokus kompetensi yang akan diteliti dalam penelitian. Kompetensi pedagogik merupakan kemampuan seseorang guru dalam melaksanakan kewajibankewajibannya secara bertanggung jawab dan layak (Anang, 2013). Semakin baik kompetensi pedagogik guru maka semakin baik pula kemampuan yang akan dimilikinya. Hal ini dikarenakan guru tersebut akan mampu melaksanakan tugas dan tanggung jawab keguruannya dalam kegiatan pendidikan dan pembelajaran dengan baik.

Menurut Kusnandar, secara makro kompetensi pedagogik guru yang diukur meliputi kemampuan guru dalam aspek; (1) memahami peserta didik secara mendalam; (2) merancang pembelajaran, termasuk memahami landasan pendidikan untuk kepentingan pembelajaran; (3) melaksanakan proses pembelajaran; (4) merancang dan melaksanakan evaluasi pembelajaran; dan (5) mengembangkan peserta didik untuk mengaktualisasikan berbagai potensinya (2007).

Adanya tuntutan kepemilikan kompetensi bagi guru oleh karena guru merupakan salah satu komponen penting dalam pendidikan dan pembelajaran di sekolah. Kedudukan guru memiliki peranan yang besar dan strategis dalam membangun sumber daya manusia jangka panjang sebagai pembangun peradaban masa depan. Gurulah yang langsung berhadapan dengan peserta didik untuk mentransfer ilmu pengetahuan dan teknologi sekaligus mendidik dengan nilai-nilai positif melalui bimbingan dan keteladanan serta melatihkan sejumlah keterampilan yang berbasis pada life skill.

Proses pendidikan dalam kegiatan pembelajaran, akan bisa berjalan dengan lancar, kondusif, interaktif, dan lain sebagainya apabila dilandasi oleh dasar kurikulum yang baik dan berkualitas. Pendidikan bisa dijalankan dengan baik ketika kurikulum menjadi penyangga utama dalam proses pembelajaran. Proses pembelajaran dapat dicapai secara optimal bila didukung oleh sumber daya guru yang profesional dan kompetabel. Oleh karena itu, kurikulum dan guru adalah ibarat dua sisi mata uang yang tidak bisa terpisahkan 
dalam mendorong pencapaian tujuan pendidikan dan pembelajaran di kelas. Bahkan, guru adalah cerminan dari kurikulum dan kurikulum adalah inheren dengan guru itu sendiri.

Dalam penyelenggaraan pendidikan di sekolah, guru mempunyai tugas dan tanggung jawab untuk melaksanakan pembelajaran dan guru menjadi eksekutif utama kurikulum. Untuk mencapai tujuan pendidikan dan pembelajaran, guru berupaya "menyampaikan" sejumlah isi kurikulum kepada peserta didik melalui proses atau strategi tertentu, serta melaksanakan evaluasi untuk mengetahui proses dan hasil pembelajaran.

Guru adalah ujung tombak dari implementasi kurikulum yang telah ditetapkan oleh pemerintah. Seberapa besar tingkat pencapaian target atau tujuan kurikulum pendidikan, sangat ditentukan pula oleh seberapa besar tingkat pemahaman dan penguasaan guru secara konseptual dan teknis implementatif terhadap kurikulum itu.

$$
\text { Menurut Indriyanto }
$$

sebagaimana dikutip Arifuddin M. Arif dan Emi Indra bahwa guru merupakan aktor terdepan dalam implementasi Kurikulum 2013. Peran penting guru antara lain meliputi: (1) kemampuan menjabarkan topik-topik bahasan pada mata pelajaran menjadi informasi yang menarik dan mudah dipahami oleh peserta didik dengan pendekatan pembelajaran sceintific, dan tematik-integratif, (2) kemampuan untuk mengidentifikasi tingkat dan area kesulitan belajar peserta didik dan kemampuan untuk membantunya keluar dari kesulitan tersebut, (3) kemampuan untuk mengembangkan bahan, media, metode dan strategi pembelajaran yang kreatif dan inovatif, dan (4) kemampuan melakukan evaluasi kemajuan belajar peserta didik yang berbasi autentik (Arif \& Indra, 2013).

Sangat tepat apa yang ditegaskan oleh Hidayat (2013) bahwa saat ini yang jauh lebih penting adalah guru sebagai ujung tombak serta garda terdepan dalam pelaksanakan kurikulum. Oleh karena itu, betapa pentingnya kesiapan guru dalam mengimplementasikan kurikulum dengan memiliki kompetensi, komitmen dan tanggung jawab.

Implementasi Kurikulum 2013 pada mata pelajaran Bahasa Arab, dapat efektif dan efesien pencapaiannya apabila didukung oleh guru Bahasa Arab yang memiliki kompetensi, baik kompetensi pedagogik, profesionalitas, kepribadian, maupun kompetensi sosial.

Berdasarkan tuntutan kompetensi guru dalam implementasi Kurikulum 2013 tersebut, Penulis bermaksud melakukan penelitian tentang kompetensi guru Bahasa Arab dalam mengimplementasikan Kurikulum 2013 dengan mengambil studi kasus pada Madrasah Tsanawiyah Negeri (MTs.N) yang ada di Kota Palu. Fokus pembahasan penelitian ini adalah kompetensi guru Bahasa Arab dalam mengimplementasikan Kurikulum 2013, kendala implementasi dan upaya peningkatan kompetensi pedagogik guru bahasa Arab pada Madrasah Tsanawiyah Negeri (MTs.N) se-Kota Palu.

\section{METODE PENELITIAN}

Jenis penelitian ini adalah penelitian kualitatif berbasis pendekatan fenomenologis, yaitu peneliti berfokus pada pendeskripsian tentang kompetensi guru Bahasa Arab dalam mengimplementasikan Kurikulum 2013 pada Madrasah Tsanawiyah Negeri (MTs.N) se-Kota Palu (Moleong, 1993). Kondisi kompetensi guru Bahasa Arab dalam pembelajaran Kurikulum 2013 tersebut berada pada kondisi yang alamiah dan tidak direkayasa. Peneliti sendiri juga instrumen kunci dalam mendeskripsikan dan menganalisis fenomena kompetensi, upaya peningkatan kompetensi, dan kendala yang terjadi dalam proses implementasian kurikulum (Yin, 2004).

Jenis data yang akan dikumpulkan dalam penelitian ini terdiri dari data primer (data pokok) dan data sekunder (data pendukung) (Spardly, 1980). Data primer penelitian ini bersumber dari para informan yang berkaitan langsung dan mengetahui secara jelas tentang permasalahan yang diteliti, yaitu guru-guru bahasa Arab yang 
ada di empat Madrasah Tsanawiyah Negeri (MTs.N) di Kota Palu, yang dipilih dengan menggunakan teknik purposive sampling (Sugiyono, 2008).

Adapun teknik pengumpulan data yang umum digunakan dalam penelitian ini adalah pengamatan atau observasi, wawancara, dan teknik dokumentasi. Berdasarkan data yang terhimpun dari hasil observasi, wawancara, dan dokumentasi selanjutnya ditelaah berkaitan kemampuan atau kompetensi pengeimplementasian kurikulum dalam pembelajaran, kendala yang dihadapi dan solusi yang ditempuh serta upaya peningkatan kompetensi guru dalam mengimplementasikan Kurikulum 2013 melalui alur teknik analisis data kualitatif menurut Miles dan Huberman (1992), yaitu: (1) reduksi data; penyajian data; dan (3) verifikasi data.

\section{HASIL DAN PEMBAHASAN}

\section{A. Kompetensi Guru Bahasa Arab Mengimplementasikan Kurikulum 2013 pada Madrasah Tsanawiyah Negeri (MTs.N) di Kota Palu}

Guru bahasa Arab adalah bagian dari barisan guru yang bertugas mendidik peserta didik di sekolah. Oleh karena itu guru bahasa Arab dituntut untuk memliki kompetensi yang memadai, terutama dalam membelajarkan Kurikulum 2013. Berhasil dan tidaknya seorang guru dalam menjalankan fungsi-fungsi pembelajaran sangat bergantung pada dimensi kompetensi yang dimiliki. Diantara kompetensi tersebut yang menjadi fokus penelitian ini adalah kompetensi pedagogik.

Kompetensi pedagogik guru bahasa Arab dilihat berdasarkan komponenkomponen, yaitu: (1) memahami peserta didik secara mendalam; (2) merancang pembelajaran, termasuk memahami landasan pendidikan untuk kepentingan pembelajaran; (3) melaksanakan proses pembelajaran; (4) merancang dan melaksanakan evaluasi pembelajaran; dan (5) mengembangkan peserta didik untuk mengaktualisasikan berbagai potensinya.

Kelima komponen kompetensi pedagogic tersebut dianalisis dengan berbasis pada konsep pembelajaran Kurikulum 2013, yaitu: kemampuan merancang perencanaan pembelajaran yang mendorong suasana pembelajarana yang berpusat pada peserta didik, menggunakan pendekatan saintifik, dan menggunakan sistem evaluasi dan penilaian autentik.

Adapun deskripsi komponenkomponen kompetensi pedagogik guru bahasa Arab di Madrasah Tsanawiyah (MTs) Negeri di Kota Palu, dideskripsikan secara kualitatif, sebagai berikut:

\section{Pemahaman terhadap peserta didik}

Kompetensi guru bahasa Arab di MTs. Negeri se-Kota Palu dalam menguasai karakteristik peserta didik penilaian 10 responden terhadap kompetensi pedagogik guru bahasa Arab dapat dipandang cukup baik berdasarkan data di mana ada $70 \%$ responden menilai bahwa guru memahami peserta didik dan $20 \%$ memberikan penilaian kurang memahami dan terdapat $10 \%$ guru dipandang tidak memahami peserta didiknya.

Adapun letak kelemahan kompetensi guru pada aspek ini, berdasarkan keterangan beberapa informan yang memberikan penilaian adalah "guru masih kurang mampu mengidentifkasi kemampuan awal peserta didik sehingga tidak mampu memberikan treatmen yang efektif untuk merangsang minat dan perhatian peserta didik untuk belajar bahasa Arab".

Meskipun ada penilaian masih kurangnya kompetensi guru pada aspek pemahaman peserta didik, namun pada umumnya penilaian responden pada prinsipnya menganggap cukup baik. Guruguru bahasa Arab pun berdasarkan keterangan wawancara dan observasi penulis memperlihatkan indikasi bahwa guru bahasa Arab cukup memahami peserta didiknya.

\section{Kompetensi dalam Merancang Pembelajaran}

Kompetensi pedagogik guru bahasa Arab terkait kemampuan merancang Rencana Pelaksanaan Pembelajaran (RPP) dapat dipandang cukup kurang atau masih lemah berdasarkan data di mana ada $50 \%$ responden menilai bahwa guru memahami peserta didik dan 30\% memberikan penilaian masih kurang mampu merancang dengan baik dan terdapat $20 \%$ guru 
dipandang tidak memiliki kemampuan merancang pembelajaran dengan baik sesuai standar dalam RPP Kurikulum 2013.

Kelemahan guru pada aspek kompetensi ini, hampir menjadi realitas yang umum. Ada budaya guru pada aspek penyusunan RPP ini yang masih memiliki kebiasaan copy paste desain RPP yang biasanya disusun sebagai contoh dan pemantik bagi guru untuk mengembangkan di masing-masing satuan pendidikan di mana guru tersebut mengajar. Sehingga guru itu kurang kreatif mengembangkan desain pembelajarannya.

Selain itu, berdasarkan pengamatan hampir RPP guru bahasa Arab di Kota Palu belum memberikan penguatan literasi dan pengarusutamaan kecakapan belajar abad 21 yang memuat 4C dan Higher of Thingking Skills (HoTS). Rancangan RPP masih sangat monoton dan hanya datar mengembangkan komponen RPP apa adanya berdasarkan apa yang ada di dalam buku guru dan buku siswa tanpa ada kreativitas dan inovasi.

\section{Kompetensi Melaksanakan Proses Pembelajaran}

Dalam konteks pembelajaran untuk mata pelajaran pada Kurikulum 2013 pendekatan pembelajaran menekankan pada berpusat pada peserta didik (student centred learning) berbasis pada pendekatan saintifik. Konteks proses pembelajaran ini, menuntut guru untuk mengembangkan proses pembelajaran yang aktif, kreatif, inovatif dan menyenangkan.

Kompetensi pedagogik guru bahasa Arab di MTs. Negeri Kota Palu terkait kemampuan menerapkan proses pembelajar dapat dipandang cukup kurang atau masih lemah berdasarkan data di mana ada 50\% responden menilai bahwa guru sudah kompeten, 30\% memberikan penilaian masih kurang mampu menerapkan proses pembelajaran sesuai standar dengan baik dan terdapat $20 \%$ guru dipandang tidak memiliki kemampuan menerapkan proses pembelajaran dengan baik sesuai standar dalam Kurikulum 2013.

Kurang optimalnya kemampuan guru bahasa Arab ini disebabkan oleh dua faktor, baik secara interal maupun secara eksternal. Faktor kurangnya kompetensi guru secara internal dipengaruhi oleh kemampuan dan kemamuan guru itu secara personal untuk mengembangkan pembelajaran secara kreatif dan inovatif. Adapun secara eksternal disebabkan oleh karakteristik, bakat, minat, dan motivasi peserta didik dalam mengikuti mata pelajaran bahasa Arab.

\section{Kompetensi Merancang dan Melaksanakan Evaluasi}

Implikasi dari proses pembelajaran adalah pelaksanaan evaluasi dan penilaian. Oleh karena itu, kemampuan atau kompetensi guru dalam merancang dan melaksanakan penilaian, baik penilaian proses maupun penilaian hasil pembelajaran mutlak dimiliki oleh seorang guru secara otentik.

Kompetensi pedagogik guru bahasa Arab terkait kemampuan merancang dan menerapkan evaluasi pembelajaran dapat dipandang cukup baik di mana ada $70 \%$ responden menilai bahwa guru sudah kompeten, 20\% memberikan penilaian masih kurang kompeten menerapkan proses perancangan dan pelaksanaan evaluasi pembelajaran sesuai standar dengan baik dan terdapat $10 \%$ guru dipandang tidak memiliki kemampuan merancang dan menerapkan proses pembelajaran dengan baik sesuai standar dalam Kurikulum 2013.

Dari proses observasi yang dilakukan, penulis melihat pada prinsipnya guru sudah merancang evaluasi. Namun dalam pengamatan penulis, rancangan tersebut meskipun sudah menyusun langkah-langkah penilaian berdasarkan standar Kuriukulum 2013, namun belum terlalu rinci pemetaan instrumen dan jenis penilaian otentik mulai dari penilaian sikap, pengetahuan, dan keterampilan yang dilengkapi dengan rubriknya.

\section{Kompetensi Mengembangkan Peserta Didik}

Subkompetensi pedagogik guru terkait dalam mengembangkan peserta didik pada fokus penelitian ini adalah kemampuan guru dalam melakukan pengembangan potensi peserta didik, terutama dalam kaitannya dengan pembelajaran bahasa Arab. Berdasarkan data, bahwa kompetensi pedagogik guru bahasa Arab terkait kemampuan 
mengembangkan potensi peserta didik dapat dipandang cukup baik di mana ada $60 \%$ responden menilai bahwa guru sudah kompeten, 20\% memberikan penilaian masih kurang kompeten dan terdapat $10 \%$ guru dipandang tidak memiliki kemampuan mengembangkan kemampuan atau potensi peserta didik.

Pengembangan potensi peserta didik yang dilakukan guru bahasa Arab terutama pada ekstrakurikuler, adalah memberikan kesempatan kepada peserta didik yang berminat dan berbakat dalam bidang keagamaan seperti seperti nasyid, baca tulis al-qur'an. Bahkan, tidak hanya dalam bidang keagamaan saja, bidang umum sekolah juga menyediakan ekskul pengembangan potensi dan bakat peserta didik seperti pramuka.

\section{B. Kendala dan Upaya}

Pengimplementasian Kurikulum 2013

Mata Pelajaran Bahasa Arab pada

Madrasah Tsanawiyah Negeri
(MTs.N) di Kota Palu

\section{Kendala Pengimplementasian}

Guru yang berkualitas akan sadar dengan kewajiban, tugas dan tanggung jawabnya dan selalu intropeksi diri serta selalu berusaha untuk melaksanakan tugasnya sebagai seorang pendidik yang berkompeten. Dengan demikian, guru dituntut untuk selalu berusaha meningkatkan kualitas kemampuannya dengan menambah pengetahuan yang dimiliki, memperkaya pengalaman ngajarnya, memperbanyak membaca buku bacaan, mengikuti seminar-seminar dan kegiatan yang lainnya. Tetapi, dalam upaya dan proses pengembangan kompetensi ini, tidak jarang terdapat hambatan-hambatan yang dialami.

Diantara hambatan dalam pengembangan kompetensi pedagogik berdasarkan penelitian ini salah satunya adalah faktor latar belakang guru yaitu usia. Ketika usia guru semakin tua, guru sudah tidak ingin lagi mengikuti pelatihan dan beliau hanya mengajar semampunya saja tanpa memenuhi syarat sebagai guru yang berkompeten. Selain itu, kurangnya sarana dan prasarana juga menjadi penghambat guru untuk lebih berkompeten dalam mengajar.

Latar belakang guru, yang menjadi hambatan dalam pengembangan kompetensi pedagogik guru adalah usia. Guru yang telah lanjut usia akan susah mengikuti perkembangan zaman, mereka hanya menuruti kemauan dirinya saja dengan mengajar sesuai keinginannya sendiri tanpa ada upaya dan motivasi diri. Selain faktor motivasi guru scara internal, terdapat pula kendala eksternal yang berkaitan dengan ketersediaan sarana dan prasarana pembelajaran yang berbasis teknologi seperti media interaktif dan laboratorium.

Dengan denikian, secara umum kendala pengimplementasian pembelajaran bahasa Arab berdasarkan standar proses dengan tingkat kompetensi pedagogik yang baik di Madrasah Tsanawiyah (MTs) Negeri di Kota Palu terdapat dua kategori, yaitu: (1) kendala internal guru yang kurang ada upaya dan motivasi untuk meningkatkan kompetensi dan kendala terkait dengan sumber dan media pembelajaran bahasa Arab; dan (2) kendala eksternal, yaitu dari tingkat motivasi, minat, dan kemampuan serta karakteristik peserta didik terhadap mata pelajaran bahasa Arab.

\section{Upaya Peningkatan Kompetensi Pedagogik}

Untuk memantapkan kompetensi pedagogik guru bahasa Arab, perlu dilakukan upaya pengembangan kompetensi pedagogik secara berkesinambungan. Adapun upaya peningkatan kompetensi pedagogik guru bahasa Arab di Madrasah Tsanawiyah Negeri di Kota Palu, adalah melakukan pelatihan-pelatihan yang bersifat in-hous training. Selain itu juga kami mengikutsertakan berupa seminar, workshop, MGMP dan pelatihan pengembangan yang lainnya.

Selain itu, upaya peningkatan kompetensi guru juga diperkuat melalui pelatihan dan pendampingan serta monev melalui intensitas supervisi pembelajaran guru, peningkatan sarana dan prasarana atau media pembelajaran yang dapat mendukung peningkatansuasana pembelajaran yang 
berkualitas, kreatif, inovatif, dan menyenangkan peserta didik.

Sebagai upaya untuk meningkatkan kompetensi, memang masih memerlukan penguatan kapasitas sumber daya, terutama berkaitan dengan perkembangan baru dari pembelajaran berdasarkan standar Kurikulum 2013. Beberapa temuan peneltian di atas mendeskripsikan bahwa sesungguhnya guru bahasa Arab di Kota Palu pada prinsipnya menyadari titik kelemahannya pada beberapa aspek komponen kompetensi, termasuk kompetensi pedagogik. Oleh karena itu, guru memerlukan upaya peningkatan kompetensi melalui berbagai cara dan upaya secara serius dan berkesinambungan, baik melalui peningkatan kapasitas maupun peningkatan sarana dan prasarana pembelajaran.

\section{KESIMPULAN}

Kompetensi pedagogik guru bahasa Arab dalam mengimplementasikan Kurikulum 2013 masih dapat dikategorikan cukup baik pada aspek sub kompetensi pada bidang pemahaman peserta didik, merancang dan melaksanakan evaluasi pembelajaran, dan pengembangan potensi peserta didik. Namun pada beberapa sub kompetensi dinilai masih lemah, yaitu pada sub kompetensi kemampuan merancang dan mengembangkan rencana pembelajaran sesuai standar Kurikulum 2013 dan tuntutan penguatan literasi, Higher of Thingking Skills (HoTS) dan 4C.

Kendala pengimplementasian Kurikulum 2013 dan penerapan kompetensi pedagogik guru bahasa Arab pada Madrasah Tsanawiyah (MTs) Negeri di Kota Palu terdiri atas dua kategori kendala, yaitu: kendala internal dan kendala eksternal. Kendala internal bersumber dari personal guru yang kurang ada motivasi dan komitmnen untuk mengembangkan diri secara mandiri. Kondisi eksternal, yaitu kurang tersedianya sarana, media, dan sumber pembelajaran bahasa Arab yang memadai dan sesuai kebutuhan pembelajaran. Selain itu, faktor peserta didik yang kurang memiliki minat dan motivasi serta kemampuan awal dalam bidang bahasa Arab. Upaya yang dilakukan dalam meningkatkan kompetensi pedagogik guru diantaranya adalah; mendorong guru secara mandiri untuk melakukan peningkatan wawasan dan kompetensi, melakukan in house training pembelajaran, pengikutsertaan dalam kegiatan pelatihan, workshop, seminar, dan peningkatan sarana dan media pembelajaran.

\section{DAFTAR PUSTAKA}

Ahsan, M., Tuntunan Mejadi Guru Profesional. Cet. I; Yogyakarta: Arruz Media, 2008.

Arif, M. Arifuddin dan Emi Indra, 5 Rukun Pembelajaran Kurikulum 2013. Palu: EnDeCe Press, 2014.

Departemen Pendidikan Nasional, UndangUndang No. 20 Tahun 2003 Tenatng Sistem Pendidikan Nasional. Bandung: CV Umbara, 2004.

Direktorat Pendidikan Agama Islam Kementrian Agama RI, Surat Keputusan (SK) Penetapan Sekolah Sasaran Implementasi Kurikulum 2013. Jakarta; tanggal 5 Juli 2013.

Kunandar, Guru Profesional. Cet. I; Jakarta: Rajawali Press, 2007.

Miles, B. Matthew dan A. Michael Huberman, Qualitative Data Analysis, diterjemahkan oleh Tjetjep Rohendi Rohidi, Analisis Data Kualitatif. Jakarta: UI Pres, 1992.

Moleong, J. Lexy, Metodologi Penelitian Kualitatif. Bandung: PT Remaja Rosdakarya, 1993.

Mulyasa, E. H., Pengembangan dan Implementasi Kurikulum 2013. Cet. IV; Bandung: PT Remaja Rosda Karya, 2014. 
Spardly, J.P., Participant Observation. New York: Holt Rinehart and Winston, 1980.

Sugiyono, Memahami Penelitian Kualitatif . Cet. I; Bandung: Alfabeta, 2008.

Yin, K. Robert, Case Studi Research Design and Methods, diterjemahkan oleh M. Djauzi Muzakkir, Studi Kasus Desain dan Metode. Jakarta: PT Raja Grafindo Persada, 2004. 